\title{
The By-products and Emissions from Manufacturing Torrefied Solid Fuel Using Waste Bamboo Chopsticks
}

\author{
Yen-Hau Chen ${ }^{1}$, Chia-Chi Chang ${ }^{1}$, Ching-Yuan Chang ${ }^{1,2, *}$, Min-Hao Yuan ${ }^{3}$, Dar-Ren Ji ${ }^{1}$, \\ Chungfang Ho ${ }^{4}$, Chyow-San Chiou ${ }^{5}$, Je-Lueng Shie ${ }^{5}$, Yi-Hung Chen ${ }^{6}$, Wei-Ren Chang ${ }^{1}$, \\ Tzu-Yi Yang ${ }^{1}$, Tsung-Chi Hsu ${ }^{1}$, Michael Huang ${ }^{1}$, Chao-Hsiung $\mathrm{Wu}^{7}$ and Far-Ching Lin ${ }^{8}$ \\ 1 Graduate Institute of Environment Engineering, National Taiwan University, Taipei 106, Taiwan; \\ p29681726@gmail.com (Y.-H.C.); d92541005@ntu.edu.tw (C.-C.C.); jdr0826@gmail.com (D.-R.J.); \\ a10022587@gmail.com (W.-R.C.); r99541115@ntu.edu.tw (T.-Y.Y.); tsungchiapp@gmail.com (T.-C.H.); \\ r01541105@ntu.edu.tw (M.H.) \\ 2 Department of Chemical Engineering, National Taiwan University, Taipei 106, Taiwan \\ 3 Department of Occupational Safety and Health, China Medical University, Taichung 404, Taiwan; \\ mhyuan0703@gmail.com \\ 4 Department of International Business, Chung Yuan Christian University, Chung-Li 320, Taiwan; \\ chunfang@cycu.edu.tw \\ 5 Department of Environmental Engineering, National I-Lan University, I-Lan 260, Taiwan; \\ cschiou@niu.edu.tw (C.-S.C.); jlshie@niu.edu.tw (J.-L.S.) \\ 6 Department of Chemical Engineering and Biotechnology, National Taipei University of Technology, \\ Taipei 106, Taiwan; yhchen1@ntut.edu.tw \\ 7 Department of Environmental Engineering, Da-Yeh University, Changhua 515, Taiwan; \\ chwu@mail.dyu.edu.tw \\ 8 Department of Forestry and Resource Conservation, National Taiwan University, Taipei 106, Taiwan; \\ farching@ntu.edu.tw \\ * Correspondence: cychang3@ntu.edu.tw; Tel.: +886-2-2363-8994
}

Academic Editor: Yu-Pin Lin

Received: 28 February 2017; Accepted: 23 April 2017; Published: 11 May 2017

\begin{abstract}
Although the main purpose of the torrefaction of biomass is to produce high quality solid bio-fuel, the by-products, including liquid and gas products, are worth investigating to know their effects on the environment and the reusable possibility. Consequently, after torrefying waste bamboo chopsticks (WBCs) for producing solid bio-fuel, the liquid and gas products were examined in this study. The torrefaction target was set to produce torrefied waste bamboo chopsticks $\left(\mathrm{WBC}_{\mathrm{T}}\right)$ retaining about $70 \mathrm{wt} \%$. A proper torrefaction temperature $\left(T_{r}\right)$ and torrefaction time $\left(t_{r}\right)$ were found at $563 \mathrm{~K}$ and $40 \mathrm{~min}$, respectively, for carrying out the torrefaction in a tubular furnace with carrier nitrogen. These conditions gave a solid yield $\left(\mathrm{Y}_{\mathrm{S}}\right)$ of $69 \mathrm{wt} \%$ of $\mathrm{WBC}_{\mathrm{T}}$ relative to the original $\mathrm{WBC}$, and $31 \mathrm{wt} \%$ of by-products were produced. The liquid products were composed of water as high as $62 \mathrm{wt} \%$, along with some organic acids. Some medicine components were also found in the liquid products, representing potential medicine applications. During torrefaction, $\mathrm{CO}, \mathrm{NO}_{\mathrm{x}}, \mathrm{SO}_{2}$, and $\mathrm{CO}_{2}$ emissions were largely discharged from 10 to 20 min of torrefaction time. $\mathrm{O}_{2}, \mathrm{CO}_{2}$, and $\mathrm{H}_{2} \mathrm{O}$ are the major compounds in the total gas products collected. Some combustible gases of $\mathrm{C} 1$ to $\mathrm{C} 6$ hydrocarbons were also produced. Moreover, the gas volume balances were computed and evaluated. The information obtained in this study is useful for the proper design, operation, pollution control, and utilization of the products.
\end{abstract}

Keywords: torrefaction; waste bamboo chopsticks; Moso bamboo; solid bio-fuel 


\section{Introduction}

Torrefaction is a feasible method to convert biomass into high quality solid bio-fuel, and the advantages, application, and future trend of biomass torrefaction have been evidently presented by several review papers [1-4]. In the past, studies have mainly focused on the solid product after torrefaction. However, the liquid and gas products, as by-products, have the same important roles because of their potential reutilization and their effects on the environment.

After torrefaction, biomass is transformed into solid, liquid, and gas parts. The components of the products of torrefaction may be different when employing different biomasses, torrefaction temperatures $\left(T_{r}\right)$, and torrefaction times $\left(t_{r}\right)$, and typical components were reported by Bergman et al. [5]. The solid phase, regarded as bio-fuel, is comprised of a chaotic structure of the original sugar structures and modified sugar structures, newly formed polymeric structures including aromatic rings, and the ash. The liquid phase is composed of water, organics (sugars, polysugars, acids, alcohols, furans, ketones), and lipids (terpenes, phenols, fatty acids, waxes, tanins), and is collected by condensing in room temperature. On the basis of references [6,7], the liquid product produced by the pyrolysis of biomass is composed of acid components, aromatic hydrocarbons, phenols, and so on. However, as for a woody plant, the pyrolysis of a different construction of lignin results in different components being present in the liquid product [8]. Thus, analyzing the collected liquid product from torrefaction is a necessary step to figure out the composition for evaluating its usefulness and for maintaining a carbon balance. Detailed liquid product analyses from the torrefaction of biomass including lauan, bamboo, willow, straw, and larch, have been conducted in several studies [9-11]. For lauan, Chen et al. [9] found that monoaromatics are the major component accompanied with a small quantity of heterocyclic hydrocarbons. Concerning bamboo, Chen et al. [10] detected the presence of acid, alcohols, ketones, phenols, aldehydes, esters, and water. The $\mathrm{pH}$ value of the liquid was as low as 2.27-2.60. Moreover, the liquid was comprised of about $50 \%$ of water. As for willow, straw, and larch, Prins et al. [11] reported the following findings: (1) Acetic acid and water are the main components of the liquid, while methanol, formic acid, lactic acid, furfural, and hydroxyl acetone are present in a smaller amount, and traces of phenol occur for the case of willow; (2) Straw presented a comparable amount of liquid products similar to those of willow; and (3) Formic acid is the major acid generated by larch. Permanent gas like $\mathrm{H}_{2}, \mathrm{CO}, \mathrm{CO}_{2}$, and $\mathrm{CH}_{4}$ can be found in the gas phase. The gas phase also contains $\mathrm{C}_{X} \mathrm{H}_{Y}$, toluene, and benzene.

In our other study [12], torrefaction was used for reusing waste bamboo chopsticks (WBCs) which are made of Moso bamboo, in order to manufacture bio-fuel. Torrefaction temperatures $\mathrm{T}_{\mathrm{r}}$ of 543, 563, and $583 \mathrm{~K}$, with various torrefaction times $t_{\mathrm{r}}$ of 20,40, and $60 \mathrm{~min}$, were employed for carrying out the torrefaction in a tubular furnace with carrier nitrogen. Appropriate $T_{r}$ and $t_{r}$ values were found at $563 \mathrm{~K}$ and $40 \mathrm{~min}$. The high heating value in dry basis $\left(\mathrm{H}_{\mathrm{HD}}\right)$ of WBC was enhanced from 4615.86 to $5506.80 \mathrm{kcal} \mathrm{kg}^{-1}$, while the energy densification factor $\left(\mathrm{E}_{\mathrm{D}}\right)$ increased to 1.19 of torrefied WBC $\left(\mathrm{WBC}_{\mathrm{T}}\right)$. The results thus deduced that the torrefaction process is advantageous to upgrade WBCs to high energy containing solid bio-fuel.

Materials similar to bamboo vinegar, which is useful for the medicine industry, can be expected to appear in the liquid product. The traditional method for manufacturing bamboo vinegar is to condense the emitted gas from the pyrolysis of bamboo charcoal at around 573-673 K [13]. Although the temperature and method for pyrolyzing the bamboo might make a difference to the composition of the liquid product compared with torrefying WBCs, the liquid product for the torrefaction of WBC at $563 \mathrm{~K}$ and $40 \mathrm{~min}$ might contain the components of bamboo vinegar, along with water and organic acids of a low carbon number, like acetic acid and carboxylic acid.

On the other hand, aromatic hydrocarbons produced from torrefaction can also be reused by employing a ring cleavage reaction such as hydrogenation, in order to form alkanes. After the ring cleavage reaction, long-chain alkanes can yield diesel fuel (C10-C40) and aviation fuel (C10-C20) by converting the liquid product in subsequent processes, including removing the acidity and other steps. As a result, it is beneficial to investigate the liquid product from the torrefaction of WBCs for finding an appropriate application for the liquid product. 
As the preprocess of producing WBCs is carried out by immersing bamboo in strong oxidizers, including sulfur, which might ruin the construction of Moso bamboo [14], gaseous sulfides may be emitted, which is the evident difference for the torrefaction of WBCs. Moreover, $\mathrm{CO}$ and $\mathrm{CO}_{2}$ are possible products from torrefaction. These pollutants should be controlled in case of a negative influence on the environment, and should be restricted to meet the air pollution standards.

Above all, although torrefying WBC can produce qualified solid biofuels, the by-products resulting from torrefaction need to be characterized, and are thus conducted in this study not only for examining their reusability, but also for controlling the pollutants emitted. This study also constructed a procedure for the analyses of the by-products, offering a reference for torrefaction industries.

\section{Experimental Methods}

\subsection{Procedure of Collecting By-Products from the Torrefaction of WBC}

The disposable bamboo chopsticks (DBC) (Songya Co., Taipei, Taiwan) were used to simulate the waste $B C(W B C)$. They were cut into pieces with a dimension of $5 \mathrm{~mm}(\mathrm{D}) \times 10 \mathrm{~mm}(\mathrm{~L})$ for manufacturing $\mathrm{WBC}_{\mathrm{T}}$ with an upgraded quality. The $\mathrm{WBC}$ torrefaction was conducted employing a tubular furnace, which is the same as that used by Chen et al., with a carrier gas of nitrogen at a flow rate of $100 \mathrm{~mL} \mathrm{~min}^{-1}$ [12]. The furnace was pre-heated to the desired pre-set torrefaction temperature $T_{r}$. The sample was then introduced into the furnace and kept there for a certain torrefaction time $t_{r}$ at constant $T_{r}$. As noticed in the previous section, the effects of $T_{r}$ of 543,563 , and $583 \mathrm{~K}$, with $t_{r}$ of 20 , 40 , and $60 \mathrm{~min}$, on the production of torrefied WBC have been examined in our previous work [12]. $\mathrm{T}_{\mathrm{r}}$ and $\mathrm{t}_{\mathrm{r}}$ values of $563 \mathrm{~K}$ and $40 \mathrm{~min}$ were found to be proper [12] and were thus chosen for further study on the characterization of the by-products and emissions produced from the torrefaction of WBC. During torrefaction, gas emissions were continually produced and were slowly transported to condensing containers by the nitrogen carrier gas. Following this, the liquid products were condensed in two containers with $273 \mathrm{~K}$, and the remaining gas products were then separated.

\subsection{Liquid Analysis}

After measuring the volume and mass of the condensed liquid products, the composition of these products were analyzed using different equipment.

The total organic carbon (TOC) content was detected by Sievers InnovOx Laboratory TOC Analyzer of FIRMWARE VERSION 3.01 OR LATER (GE Analytical Instruments, Boulder, CO, USA). In this analysis, the liquid product diluted to $1 / 1000$ was taken as the sample to be tested. By using the moisture titrator (model 851 Titrando, Karl Fischer Titrators, Coulometric, Metrohm, Riverview, FL, USA), the water content was detected with the method of Karl Fischer.

The equipment for simulated distillations of the liquid product from torrefaction and various oils to determine the carbon number of organic compounds, included gas chromatography with a flame ionization detector (FID) (Agilent 6890 Chemstation, Hewlett Packard Inc., Wilmington, DE, USA), equipped with a column (UA-1 (HT) with $15 \mathrm{~m}$ length $\times 0.53 \mathrm{~mm}$ ID $\times 0.25 \mu \mathrm{m}$ thickness, Frontier Laboratories Ltd., Fukushima, Japan) and an integrator (HP 3395, Agilent Technologies Inc., Santa Clara, CA, USA).

As for identifying the organic component of the liquid product from torrefaction, a gas chromatography mass spectrophotometer, also called GC-MS (Thermo Scientific FOCUS GC Gas Chromatograph 1255080, Thermo Fisher Scientific Inc., Waltham, MA, USA), was used, adapting column Trace TR-1701 with a $30 \mathrm{~m}$ length, $0.25 \mathrm{~mm}$ ID, and $0.25 \mu \mathrm{m}$ film thickness (Thermo Fisher Scientific Inc., Waltham, MA, USA). Helium was used as the carrier gas in this system.

\subsection{Gas Analysis}

The concentrations of the different components of gases were analyzed by both instant and accumulative analyses. The instant gas concentrations were detected every minute. Additionally, the 
accumulative gas was collected in resident time using a sampling bag (Cat. No. 232-01, SKC Gulf Coast Inc., Houston, TX, USA) for analysis.

The equipment for analyzing the organic components of the gas product in the sampling bag included gas chromatography with a flame ionization detector (Agilent 6890 Chemstation, Hewlett Packard Inc., Wilmington, DE, USA), adopting a column (AB-5 with $30 \mathrm{~m}$ length, $0.32 \mathrm{~mm}$ ID, and $0.5 \mu \mathrm{m}$ film thickness, Abel Industries, Dumfries, VA, USA) and an integrator (HP 3395). The main components detected were alkanes and other hydrocarbons. The relative humidity of the gas product was measured by Hygropalm (HP22-A, Rotronic, Bassersdorf, Switzerland). By measuring the temperature, pressure, and volume of the gas in the gas bag, the water content could be calculated.

Carbon monoxide, $\mathrm{NO}_{\mathrm{x}}, \mathrm{SO}_{2}$ (ppmv), and $\mathrm{O}_{2}$ ( $\mathrm{vol} \%$ ) could be detected instantly (per min) using a gas analysis detector (Tempest 100, Telegan Gas Monitoring Ltd., Abingdon, Oxfordshire, UK). On the other hand, all emissions could also be collected in a gas bag through the whole torrefaction process, and the average content of $\mathrm{CO}, \mathrm{NO}_{x}, \mathrm{SO}_{2}$, and $\mathrm{O}_{2}$ could then be detected.

As for carbon dioxide, the emissions from the torrefaction process were collected in gas bags in two ways. Sequential samples collected every $10 \mathrm{~min}$ were used to examine the trend of $\mathrm{CO}_{2}$ emission through torrefaction. Moreover, accumulated sampling until the end of torrefaction was employed to evaluate the average $\mathrm{CO}_{2}$ content. The content of $\mathrm{CO}_{2}$ was analyzed by a gas analyzer (HM5000, Infrared Industries Inc., Hayward, CA, USA). The unit of $\mathrm{CO}_{2}$ concentration is vol \%.

\section{Results and Discussion}

\subsection{Composition of Solid, Liquid, and Gas Produts from the Torrefaction of WBC at $563 \mathrm{~K}$ and $40 \mathrm{~min}$}

After the process of torrefying $\mathrm{WBC}$ at $563 \mathrm{~K}\left(290^{\circ} \mathrm{C}\right)$ and $40 \mathrm{~min}$ was finished, masses of the torrefied solid product $\mathrm{WBC}_{\mathrm{T}}$, liquid product, and gas product produced through the process were collected. A mass balance of three products was built to generate a detailed analysis, as presented in Table 1. A comparison of the mass, yield, and volume between the three products could deduce some information. Moreover, after analyzing the compositions of the solid, liquid, and gas, a more specific calculation and balance could be achieved by incorporating the information of the mass and volume of the liquid and gas, as well as the mass of the solid products.

Table 1. Solid, liquid, and gas products from the torrefaction of waste bamboo chopstick (WBC) at $563 \mathrm{~K}$ and $40 \mathrm{~min}$.

\begin{tabular}{|c|c|c|c|c|c|c|c|c|}
\hline $\begin{array}{c}\mathrm{T}_{\mathrm{r}}-\mathrm{t}_{\mathrm{r}} \\
(\mathrm{K}-\mathrm{min})\end{array}$ & & $\begin{array}{c}\text { Mass }^{a} \\
\text { (g) }\end{array}$ & & & $\begin{array}{l}\text { ass Yield } \\
(-)\end{array}$ & & & me \\
\hline \multirow{2}{*}{$563-40$} & Solid $^{\mathrm{b} 1}$ & Liquid & Gas $^{c}$ & Solid $^{\mathrm{b} 1}$ & Liquid & Gas $^{c}$ & Liquid & Gas $^{c}$ \\
\hline & $2.07^{b 2}$ & 0.43 & 0.51 & $0.69^{b 2}$ & 0.14 & 0.17 & $0.41(0.03)^{\mathrm{e}}$ & $183^{d}(27.1)^{e}$ \\
\hline
\end{tabular}

${ }^{a}$ Initial mass of dried WBC $=3$ g. ${ }^{\text {b1 }}$ Dry basis; ${ }^{\text {b2 }}$ Data of Chen et al. [12]. ${ }^{\mathrm{c}}$ Excluding nitrogen gas; flow rate

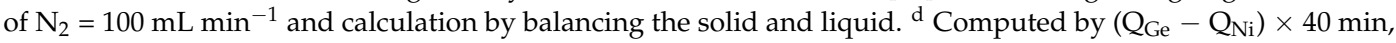
where $Q_{\mathrm{Ge}}$ and $\mathrm{Q}_{\mathrm{Ni}}$ are the average flow rates of the exit gas and inlet $\mathrm{N}_{2}$, respectively, which were 104.58 and

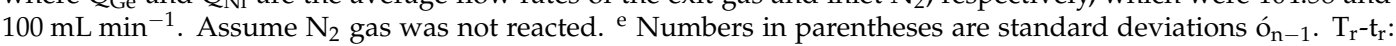
Torrefaction temperature and time.

The main part of the products is the solid product, which consists of $69 \mathrm{wt} \%$ of the total products. Due to pyrolysis with a mild temperature at $563 \mathrm{~K}\left(290{ }^{\circ} \mathrm{C}\right)$, only moderate devolatilisation and carbonization occurred. In the end, the torrefied solid fuel was the main product after torrefaction. The mass yields of the liquid and gas products are 0.14 and 0.17 , respectively. Notice that more gas is obtained than liquid, which is different to the findings of Prins et al. [11] and Le Thanh et al. [15]. This may be caused by the following: (1) The raw materials used were different, with WBC being employed in this study, and willow, straw, and larch being used by Prins et al. [11], and pine, ash wood, miscanthus, and wheat straw being used by Le Thanh et al. [15]; (2) Different condensation temperatures were employed at $273 \mathrm{~K}\left(0{ }^{\circ} \mathrm{C}\right), 268 \mathrm{~K}\left(-5^{\circ} \mathrm{C}\right)$, and $253 \mathrm{~K}\left(-20{ }^{\circ} \mathrm{C}\right)$ by this work, 
Prins et al. [11], and Le Thanh et al. [15], respectively; and (3) A small portion of liquid products may be condensed and trapped along the transmitting tube, but not in the condensate collector.

Because the mass and volume of the liquid are $0.425 \mathrm{~g}$ and $0.41 \mathrm{~mL}$, respectively, the density of the liquid product is $1.04 \mathrm{~g} \mathrm{~mL}^{-1}$, which is close to that of water, and this result also proves that the main component of the liquid product is water, which is discussed later in Section 3.2.1 with Figure 1. The volume of gas products without the carrier gas is $183 \mathrm{~mL}$, while the mass is $0.505 \mathrm{~g}$. The density of the gas products is about $2.76 \times 10^{-3} \mathrm{~g} \mathrm{~mL}^{-1}$, indicating the presence of light gases.

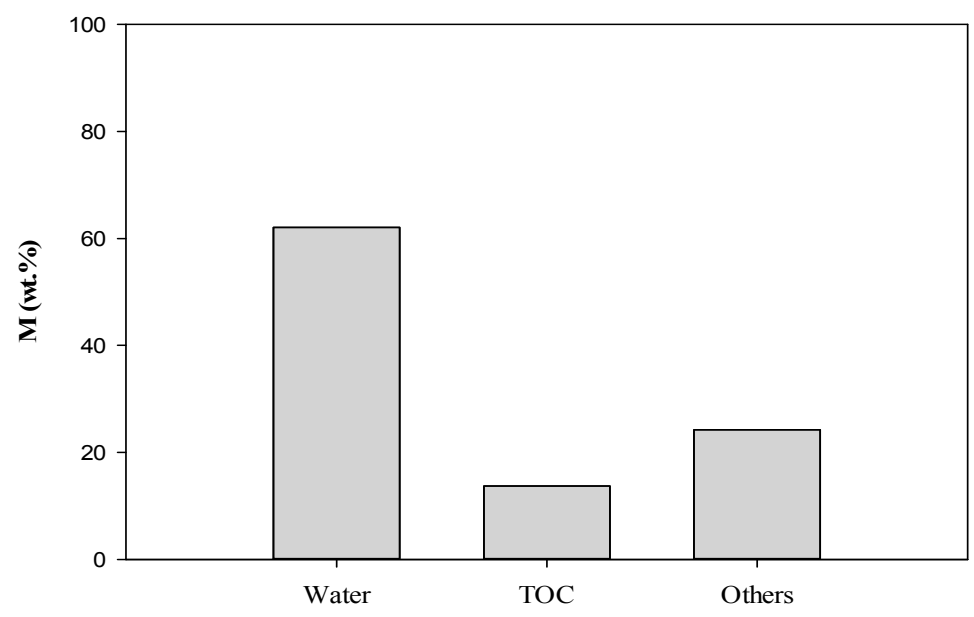

Figure 1. Mass percents (M) of water, total organic carbon (TOC), and others in the liquid products produced from the torrefaction of waste bamboo chopstick (WBC) at $563 \mathrm{~K}$ and $40 \mathrm{~min}$. Concentration of TOC $\left(C_{\mathrm{TOC}}\right)=137,000 \mathrm{mg} \mathrm{L}^{-1}$. Mass of liquid products $\left(\mathrm{m}_{\mathrm{L}}\right)=0.43 \mathrm{~g}$ and volume of liquid products $\left(\mathrm{V}_{\mathrm{L}}\right)=0.41 \mathrm{~mL}$.

\subsection{Liquid Products from the Torrefaction of WBC at $563 \mathrm{~K}$ and $40 \mathrm{~min}$}

\subsubsection{TOC and Water}

A liquid product with a moderate brown color was condensed and collected in a glass container. Analyses of the water content, total organic content (TOC), and the characteristics of the organic components in the liquid product were conducted.

Figure 1 shows the mass percentages (M) of TOC, water, and others (the residual mass excluding water and TOC) in the liquid product. The water content (62 wt \%) in the liquid product might result from the reaction of pyrolyzing WBCs and water in cells of WBCs which couldn't be removed from drying at $378 \mathrm{~K}\left(105^{\circ} \mathrm{C}\right)$. Moreover, the moisture in the air sliding in would bring in some water during the loading of WBCs in torrefaction. The moisture can be easily condensed in a glass container surrounded by $273 \mathrm{~K}\left(0{ }^{\circ} \mathrm{C}\right)$ of water and contributed to the water content in the liquid product. In comparison, $51 \%$ of the moisture content in the liquid product from bamboo torrefaction at $573 \mathrm{~K}$ for 60 min can be found in Chen's study [10], which also indicates that water is the major component in the liquid product after torrefaction.

Using a TOC analyzer, the concentration of TOC $\left(\mathrm{C}_{\mathrm{TOC}}\right)$ of the liquid product can be measured with $137,000 \mathrm{mg} \mathrm{L}^{-1}$. Consequently, with a volume of liquid product $\left(\mathrm{V}_{\mathrm{L}}\right)$ of $0.41 \mathrm{~mL}$ and a mass of liquid product $\left(\mathrm{m}_{\mathrm{L}}\right)$ of $0.43 \mathrm{~g}$, the mass percentage of TOC $\left(\mathrm{M}_{\mathrm{TOC}}\right)$ can be calculated by the formula listed below:

$$
\mathrm{M}_{\mathrm{TOC}}=\left(\mathrm{C}_{\mathrm{TOC}} \times \mathrm{V}_{\mathrm{L}} / \mathrm{m}_{\mathrm{L}}\right) \times 100 \mathrm{wt} \%
$$

Roughly, an $\mathrm{M}_{\mathrm{TOC}}$ value of $13 \mathrm{wt} \%$ was obtained. The content of the others, excluding water, was $25 \mathrm{wt} \%$. The compounds of TOC can be further identified by GC-MS. 


\subsection{2. $\mathrm{pH}$ Value}

Using a $\mathrm{pH}$ meter, the diluted liquid of $1 / 100$ from the original liquid product was measured with $\mathrm{pH}=2.96$, indicating that the components in the liquid contain acid matters. The $\mathrm{pH}$ value of the un-diluted liquid is 0.96 , assuming that the $\mathrm{H}^{+}$of the acid matters can be totally dissociated. The acidity can be inferred to be caused by the organic acids from the pyrolysis of WBCs, supported by the reference mentioned previously. Another source of acidity comes from the inorganic acids, which are probably generated by the reactions between the gaseous emissions in the furnace of $\mathrm{CO}_{2}$ and $\mathrm{H}_{2} \mathrm{O}$, and $\mathrm{SO}_{2}$ and $\mathrm{H}_{2} \mathrm{O}$ (the gas products discussed in Section 3.3.2), which would form acid materials like $\mathrm{H}_{2} \mathrm{CO}_{3}$ and $\mathrm{H}_{2} \mathrm{SO}_{3}$. The formation of $\mathrm{SO}_{2}$ is due to the sulfur-treated preprocess of the bamboo chopsticks described in the introduction. As a result, the $\mathrm{pH}$ value of the liquid product in this study is much lower than that of 2.27 to 2.60 from bamboo torrefaction [10].

\subsubsection{Simulated Distillation}

For the sake of determining the distribution of organic compounds of different boiling points (bps) in the liquid product, simulated distillation gives an index to compare the liquid product with different oils. From the simulated distillation in Figure 2, the major compositions, excluding the water of the liquid products, are low bp organic compounds $(\mathrm{bp}<341 \mathrm{~K})$ which have a carbon number below C6. The results of the liquid products are more similar with gasolines 92, 95, and 98, which are comprised of isooctane (C8) and heptane (C7) with a low carbon number [16].

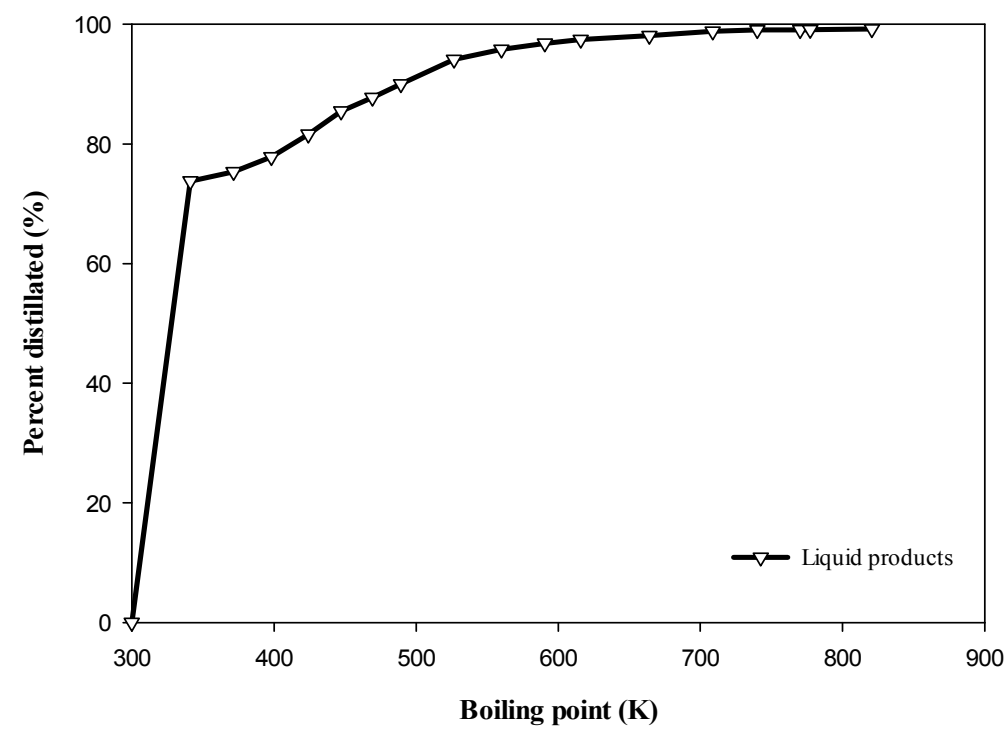

Figure 2. Simulated distillation of liquid products from the torrefaction of WBC at $563 \mathrm{~K}$ and $40 \mathrm{~min}$.

The traditional way to produce bamboo vinegar is to condense the gas products obtained from the pyrolysis of bamboo charcoal at about 573-673 K [13]. Although the temperature and method for pyrolyzing the bamboo might make a difference to the composition of the liquid product compared with torrefying WBCs, the liquid product from the torrefaction of WBC at $563 \mathrm{~K}$ and $40 \mathrm{~min}$ might contain the components of bamboo vinegar. Noting the acidity of the liquid products, it can be deduced that organic acids of a low carbon number probably include acetic acid and carboxylic acid, which are the primary chemicals in bamboo vinegar. The stationary phase in a column of GC-FID is $100 \%$ dimethylpolysiloxane, which is nonpolar. Van der Waals' force is the main factor of the mechanism used to separate compounds of liquids. Materials exhibit different detention times in a column because of the different degree of interacting with the stationary phase by Van der Waals' force. As a result, polar materials will appear prior to nonpolar materials, due to the stronger attraction between the nonpolar materials and stationary phase. 
In Figure 2, the bp is seen to increase with the detention time. The standard oils are primarily nonpolar, so the molecular weight is the factor of the separation temperature. As to the liquid product, 74 area $\%$ at $341 \mathrm{~K}$ indicates that acidic organic compounds with a polar property have a short detention time and occur at a low temperature, before the nonpolar materials. Consequently, the compounds contributing to the peaks within 74 area \% might contain organic acids with a carbon number up to C6. Notice that it is not easy to separate useful compounds from pyroligneous liquor. However, the study of Wang et al. [17] was dedicated to extracting useful materials from wood vinegar. The study reported the concentrating of acetol from wood vinegar by distillation and solvent extraction, which successfully concentrated acetol from $1 \%$ to $40 \%$. Accordingly, medicine materials in pyroligneous liquor might be separated by different boiling points and proper extracting solvent. Further studies would certainly be helpful to verify the validity of the distillation-extraction process.

\subsubsection{Probable Organic Compounds}

In order to understand the detail composition of the liquid product, the probable organic compounds were determined by GC-MS. From the GC-MS spectrum in Figure 3, some evident signal peaks were identified and sophisticated analyses for the components of the liquid products were carried out using those peaks by GC-MS. From the data base, the probability of every compound in each signal with a specific appearing time and temperature can be listed and three of the most probable compounds of every peak were then selected, as shown in Table 2. GC-MS only detects compounds with a high carbon number $>\mathrm{C} 14$, which are a minor part in the liquid products. Among those compounds chosen for each peak, some compounds are useful and are re-listed in Table 3. These include organic components of long-chain alkanes, such as C16 hexadecane, C18 octadecane, and C21 heneicosane, which can produce diesel fuel or aviation fuel. Others include C22 colchicine, C23 prednisolone acetate, and C28 beclomethasone which have bonds with oxygen, chlorine, and nitrogen, respectively. Thus, a lot of useful compounds can be detected in the liquid products. However, torrefaction is mild pyrolysis. The temperature is still too low to break the structure of the complicated organic compounds in WBC. The detected signal of long-chain alkanes might be the cycloalkanes which still have to go through a ring cleavage reaction by hydrogenation to form alkanes. After the ring cleavage reaction, long-chain alkanes can yield diesel fuel (C10-C40) and aviation fuel (C10-C20) by converting the liquid product in subsequent processes, including removing the acidity and other steps. Moreover, C23 prednisolone acetate, C22 colchicine, and C28 beclomethasone are useful in medical science. C23 prednisolone acetate is purposed to diminish inflammation and relieve the symptoms of an allergy, and C22 colchicine can be used to treat gout and Familial Mediterranean fever. C28 beclomethasone is a steroid. It can prevent the release of substances in the body that cause inflammation. However, because of its high acidity, the application of the liquid product may be restricted in industries. The corrosivity of the liquid would lead to destroying the container or equipment. Fortunately, a hydrothermal process can be introduced to decrease the acidity and oxygen content in the liquid products for the sake of improving the quality of the liquid products which can be converted to biodiesel [16,18].

The major components in the liquid products, except water, are organic compounds with carbon. Above all, the liquid products from the torrefaction of WBC can be regarded as pyroligneous liquor, which has an economical value in industries and medicine. 
Table 2. GC-MS results of liquid products from the torrefaction of WBC at $563 \mathrm{~K}$ and $40 \mathrm{~min}$.

\begin{tabular}{|c|c|c|c|c|}
\hline Time (min) & Temperature $\left({ }^{\circ} \mathrm{C}\right)$ & Possible Compound & Probability (\%) & Formula \\
\hline 51.1 & 142.1 & $\begin{array}{l}\text { Tetradecane } \\
\text { Hexadecane } \\
\text { Pentadecane }\end{array}$ & $\begin{array}{l}51.34 \\
13.16 \\
12.65\end{array}$ & $\begin{array}{l}\mathrm{C}_{14} \mathrm{H}_{30} \\
\mathrm{C}_{16} \mathrm{H}_{34} \\
\mathrm{C}_{15} \mathrm{H}_{32}\end{array}$ \\
\hline 57.5 & 155.0 & $\begin{array}{l}\text { Pentadecane } \\
\text { Hexadecane } \\
\text { Eicosane }\end{array}$ & $\begin{array}{c}46.03 \\
13.29 \\
9.91 \\
\end{array}$ & $\begin{array}{l}\mathrm{C}_{15} \mathrm{H}_{32} \\
\mathrm{C}_{16} \mathrm{H}_{34} \\
\mathrm{C}_{20} \mathrm{H}_{42} \\
\end{array}$ \\
\hline 63.6 & 167.1 & $\begin{array}{c}\text { Hexadecane } \\
\text { Heptadecane } \\
\text { Eicosane }\end{array}$ & $\begin{array}{c}46.33 \\
10.22 \\
8.03\end{array}$ & $\begin{array}{l}\mathrm{C}_{16} \mathrm{H}_{34} \\
\mathrm{C}_{17} \mathrm{H}_{36} \\
\mathrm{C}_{20} \mathrm{H}_{42}\end{array}$ \\
\hline 69.3 & 178.6 & $\begin{array}{c}\text { Heptadecane } \\
\text { Hexadecane } \\
\text { Pentadecane, 2-methyl- }\end{array}$ & $\begin{array}{c}45.90 \\
11.34 \\
9.14 \\
\end{array}$ & $\begin{array}{l}\mathrm{C}_{17} \mathrm{H}_{36} \\
\mathrm{C}_{16} \mathrm{H}_{34} \\
\mathrm{C}_{16} \mathrm{H}_{34} \\
\end{array}$ \\
\hline 74.8 & 189.6 & $\begin{array}{c}\text { Octadecane } \\
\text { Heneicosane } \\
\text { Eicosane }\end{array}$ & $\begin{array}{l}26.91 \\
13.88 \\
12.08 \\
\end{array}$ & $\begin{array}{l}\mathrm{C}_{18} \mathrm{H}_{38} \\
\mathrm{C}_{21} \mathrm{H}_{44} \\
\mathrm{C}_{20} \mathrm{H}_{42} \\
\end{array}$ \\
\hline 80.0 & 200.0 & $\begin{array}{l}\text { Nonadecane } \\
\text { Tetracosane } \\
\text { Heneicosane }\end{array}$ & $\begin{array}{l}19.17 \\
16.94 \\
12.63 \\
\end{array}$ & $\begin{array}{l}\mathrm{C}_{19} \mathrm{H}_{40} \\
\mathrm{C}_{24} \mathrm{H}_{50} \\
\mathrm{C}_{21} \mathrm{H}_{44} \\
\end{array}$ \\
\hline 85.0 & 209.9 & $\begin{array}{c}\text { Heneicosane } \\
\text { Tetracosane } \\
\text { Eicosane }\end{array}$ & $\begin{array}{c}27.05 \\
26.00 \\
7.08 \\
\end{array}$ & $\begin{array}{l}\mathrm{C}_{21} \mathrm{H}_{44} \\
\mathrm{C}_{24} \mathrm{H}_{50} \\
\mathrm{C}_{20} \mathrm{H}_{42} \\
\end{array}$ \\
\hline 89.7 & 219.4 & $\begin{array}{c}\text { Heneicosane } \\
\text { Pentadecane, 2-methyl- } \\
\text { Octacosane }\end{array}$ & $\begin{array}{c}32.52 \\
9.91 \\
8.37\end{array}$ & $\begin{array}{l}\mathrm{C}_{21} \mathrm{H}_{44} \\
\mathrm{C}_{16} \mathrm{H}_{34} \\
\mathrm{C}_{28} \mathrm{H}_{58} \\
\end{array}$ \\
\hline 94.3 & 228.6 & $\begin{array}{c}\text { Hydrocortisone acetone } \\
\text { Digitoxin } \\
\text { Docosane }\end{array}$ & $\begin{array}{c}14.96 \\
14.38 \\
9.00 \\
\end{array}$ & $\begin{array}{c}\mathrm{C}_{23} \mathrm{H}_{32} \mathrm{O}_{6} \\
\mathrm{C}_{41} \mathrm{H}_{64} \mathrm{O}_{13} \\
\mathrm{C}_{22} \mathrm{H}_{46} \\
\end{array}$ \\
\hline 102.1 & 244.2 & $\begin{array}{l}\text { Prednisolone acetate } \\
\text { Beclomethasone } \\
\text { Colchicine }\end{array}$ & $\begin{array}{l}20.37 \\
16.41 \\
15.78 \\
\end{array}$ & $\begin{array}{l}\mathrm{C}_{23} \mathrm{H}_{30} \mathrm{O}_{6} \\
\mathrm{C}_{28} \mathrm{H}_{37} \mathrm{ClO}_{7} \\
\mathrm{C}_{22} \mathrm{H}_{25} \mathrm{NO}_{6} \\
\end{array}$ \\
\hline 107.5 & 255.0 & $\begin{array}{l}\text { Prednisolone acetate } \\
\text { Colchicine } \\
\text { Beclomethasone }\end{array}$ & $\begin{array}{l}18.65 \\
17.92 \\
11.22 \\
\end{array}$ & $\begin{array}{l}\mathrm{C}_{23} \mathrm{H}_{30} \mathrm{O}_{6} \\
\mathrm{C}_{22} \mathrm{H}_{25} \mathrm{NO}_{6} \\
\mathrm{C}_{28} \mathrm{H}_{37} \mathrm{ClO}_{7} \\
\end{array}$ \\
\hline 112.6 & 265.2 & $\begin{array}{l}\text { Colchicine } \\
\text { Prednisolone acetate } \\
\text { Beclomethasone }\end{array}$ & $\begin{array}{l}23.89 \\
12.32 \\
11.34 \\
\end{array}$ & $\begin{array}{l}\mathrm{C}_{22} \mathrm{H}_{25} \mathrm{NO}_{6} \\
\mathrm{C}_{23} \mathrm{H}_{30} \mathrm{O}_{6} \\
\mathrm{C}_{28} \mathrm{H}_{37} \mathrm{ClO}_{7}\end{array}$ \\
\hline 117.4 & 274.7 & $\begin{array}{l}\text { Prednisolone acetate } \\
\text { Beclomethasone } \\
\text { Colchicine }\end{array}$ & $\begin{array}{l}22.65 \\
18.25 \\
12.16\end{array}$ & $\begin{array}{l}\mathrm{C}_{23} \mathrm{H}_{30} \mathrm{O}_{6} \\
\mathrm{C}_{28} \mathrm{H}_{37} \mathrm{ClO}_{7} \\
\mathrm{C}_{22} \mathrm{H}_{25} \mathrm{NO}_{6}\end{array}$ \\
\hline 121.8 & 280.0 & $\begin{array}{c}\text { Colchicine } \\
\text { Colchicine, }(+)- \\
\text { Pregn-4-ene-3,20-dione, 11-hydroxy-, }(11 \alpha) \text {-- }\end{array}$ & $\begin{array}{c}47.95 \\
12.81 \\
8.02 \\
\end{array}$ & $\begin{array}{r}\mathrm{C}_{22} \mathrm{H}_{25} \mathrm{NO}_{6} \\
\mathrm{C}_{22} \mathrm{H}_{25} \mathrm{NO}_{6} \\
\mathrm{C}_{21} \mathrm{H}_{30} \mathrm{O}_{3} \\
\end{array}$ \\
\hline 125.9 & 281.9 & $\begin{array}{l}\text { Prednisolone acetate } \\
\text { Gamabufotalin } \\
\text { Beclomethasone }\end{array}$ & $\begin{array}{l}27.13 \\
18.07 \\
13.84 \\
\end{array}$ & $\begin{array}{r}\mathrm{C}_{23} \mathrm{H}_{30} \mathrm{O}_{6} \\
\mathrm{C}_{24} \mathrm{H}_{34} \mathrm{O}_{5} \\
\mathrm{C}_{28} \mathrm{H}_{37} \mathrm{ClO}_{7}\end{array}$ \\
\hline 134.0 & 298.0 & $\begin{array}{l}\text { Prednisolone acetate } \\
\text { Colchicine } \\
\text { Colchicine, }(+)-\end{array}$ & $\begin{array}{c}48.90 \\
17.86 \\
4.27\end{array}$ & $\begin{array}{l}\mathrm{C}_{23} \mathrm{H}_{30} \mathrm{O}_{6} \\
\mathrm{C}_{22} \mathrm{H}_{25} \mathrm{NO}_{6} \\
\mathrm{C}_{22} \mathrm{H}_{25} \mathrm{NO}_{6}\end{array}$ \\
\hline
\end{tabular}


Table 3. Structure of useful and possible compounds of liquid products for producing $\mathrm{WBC}_{\mathrm{T}}$.

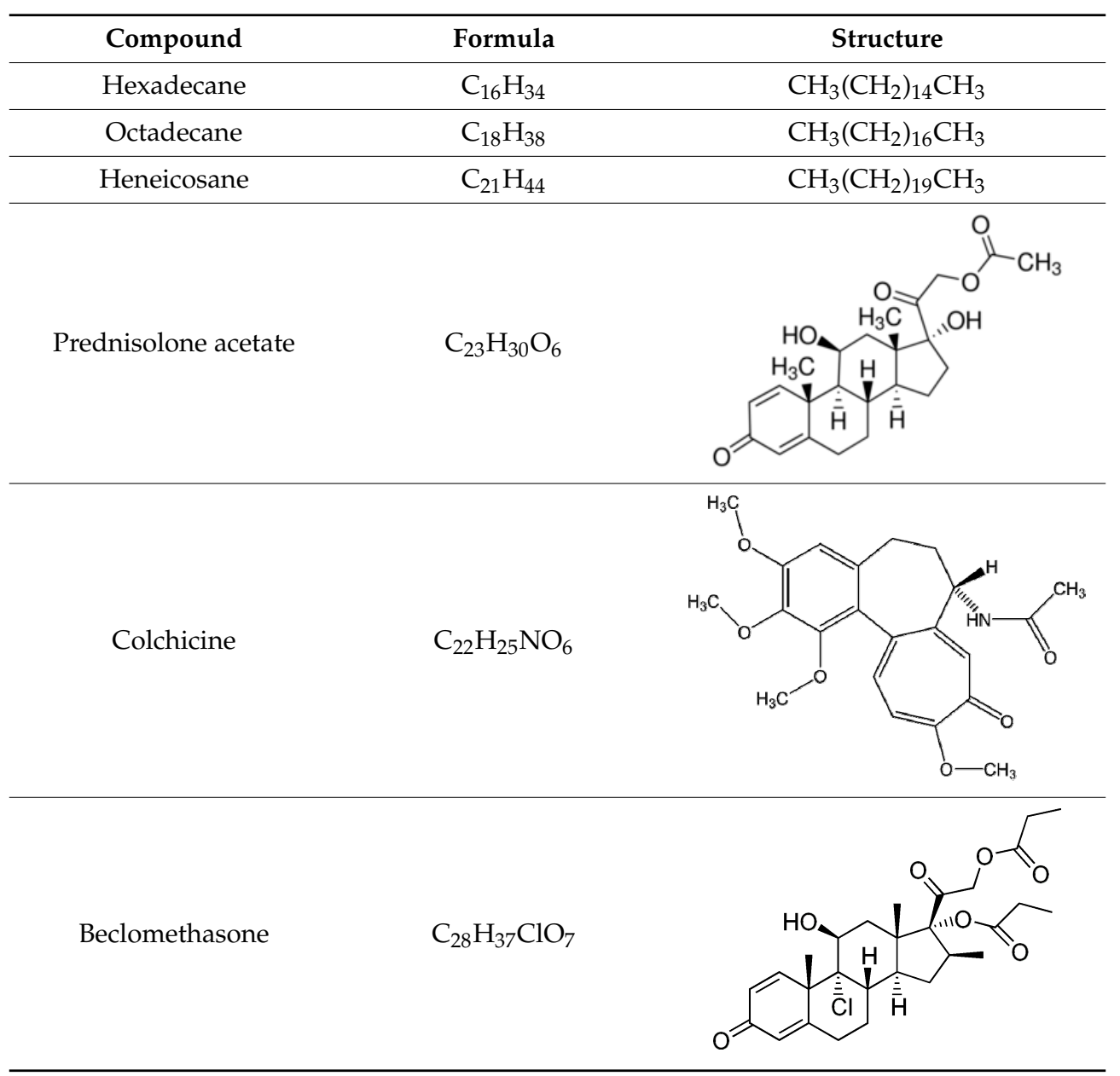

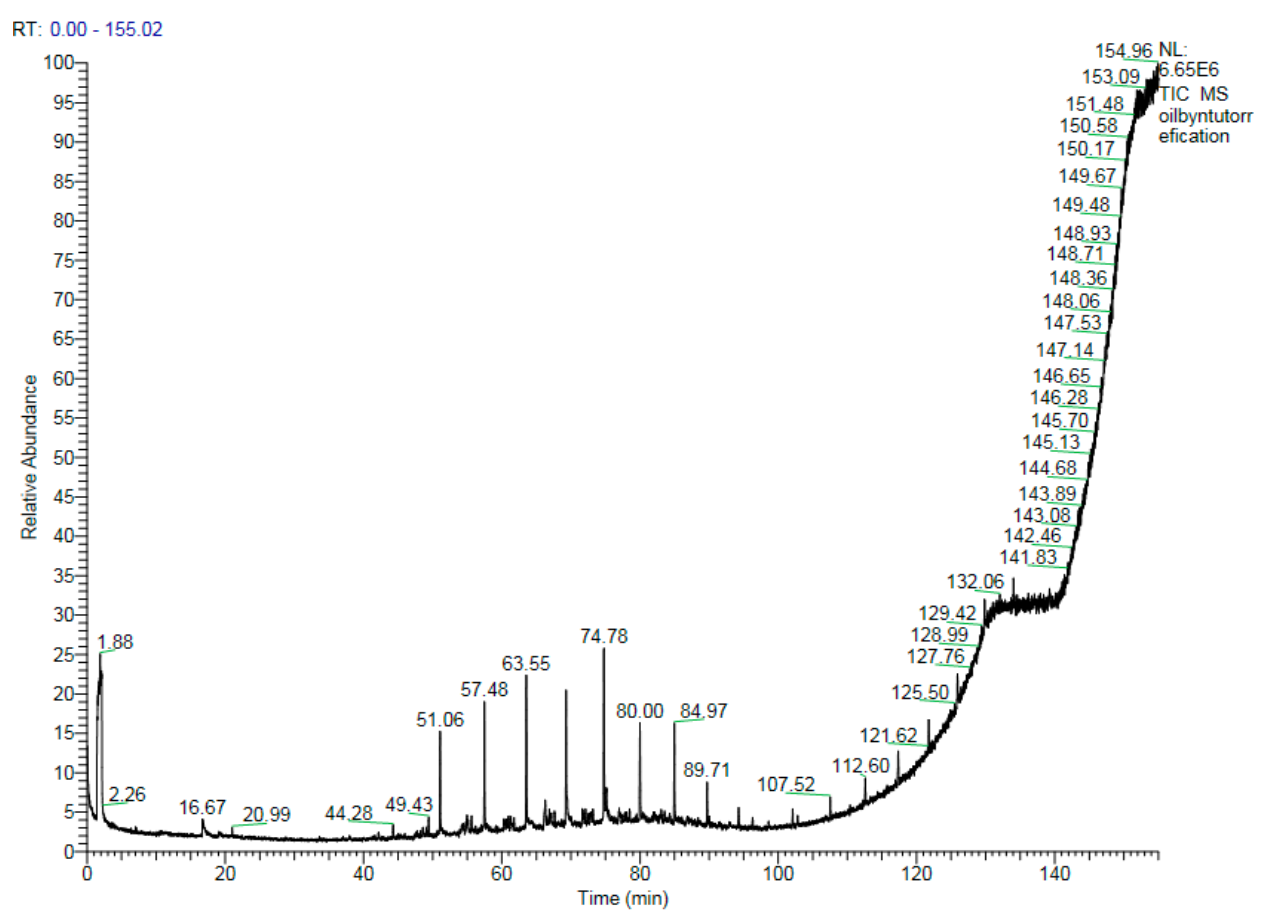

Figure 3. GC-MS spectrum of liquid products from the torrefaction of WBC at $563 \mathrm{~K}$ and $40 \mathrm{~min}$. 


\subsection{Gas Products from the Torrefaction of WBC at $563 \mathrm{~K}$ and $40 \mathrm{~min}$}

\subsubsection{Hydrocarbons}

The emissions from the torrefaction process contain hydrocarbons (HCs) of a lower carbon number $(\mathrm{Cn})$. When analyzing the emitted gas of the whole process through GC-FID, the basic composition of the hydrocarbons in the gas could be determined. By different volumes $(10,15,20,25,30 \mu \mathrm{L})$ of a standard sample of alkanes which contains $\mathrm{CH}_{4}, \mathrm{C}_{2} \mathrm{H}_{6}, \mathrm{C}_{3} \mathrm{H}_{8}, \mathrm{C}_{4} \mathrm{H}_{10}, \mathrm{C}_{5} \mathrm{H}_{12}$, and $\mathrm{C}_{6} \mathrm{H}_{14}$ with a concentration of 1000 ppmv, the calibration line of each alkane was established for the relationship between the area of the signal and the amount of standard sample injected. The peaks of the signal from the standard sample stand for the hydrocarbons which appear at different times, and the sequence of their appearance is decided by the carbon number. The lower the carbon number is, the sooner the peak appears.

Through GC-FID, the spectrum of the gaseous products from the torrefaction of $\mathrm{WBC}_{\mathrm{T}}$ is illustrated in Figure 4. Many peaks can be seen, representing different appearance times. Compared with the GC-FID spectrum of the standard gases of hydrocarbons, the peaks could be sorted according to the similar chemical polarity of the alkanes.

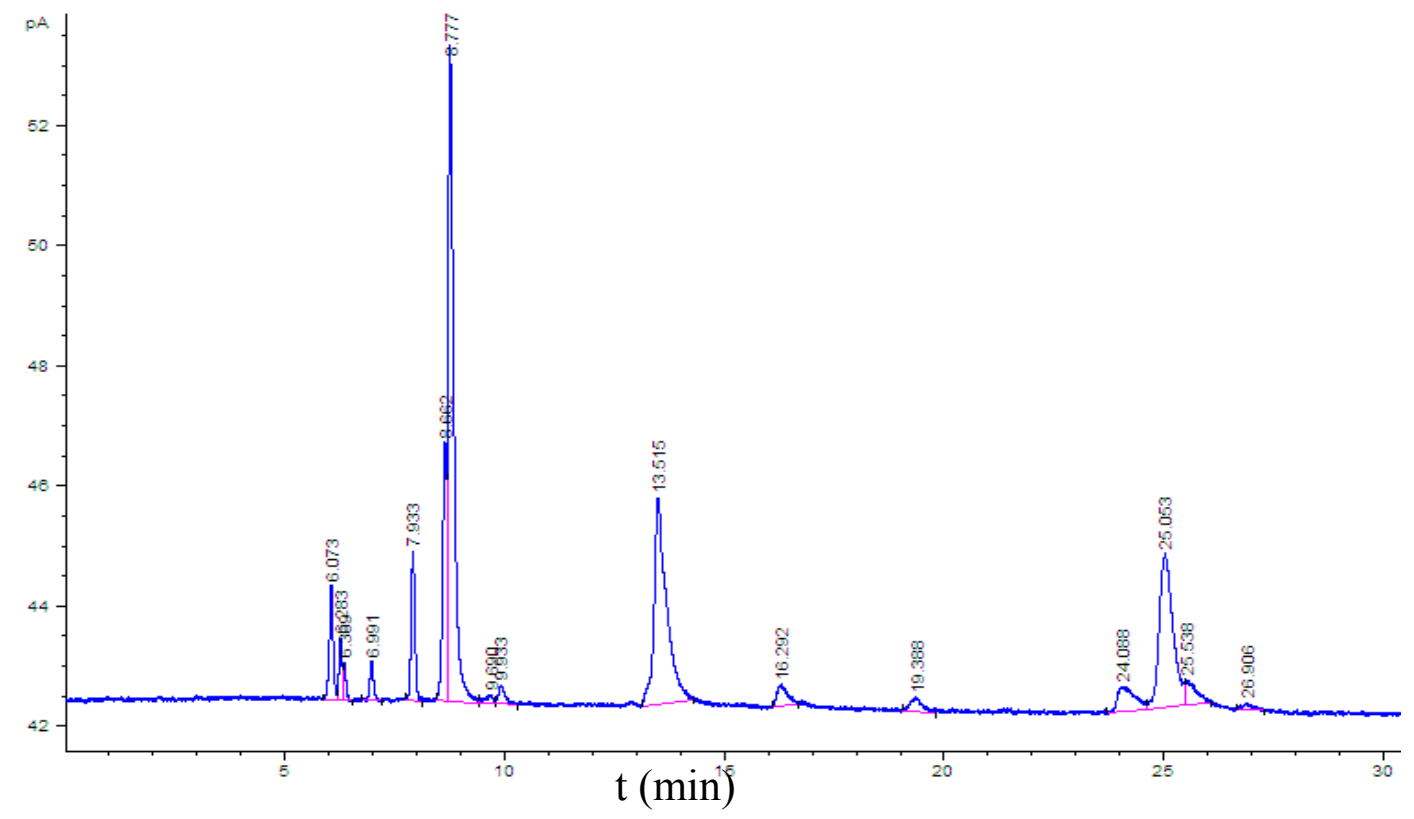

Figure 4. GC-FID spectrum of gaseous products from the torrefaction of WBC at $563 \mathrm{~K}$ and $40 \mathrm{~min}$. Volume of gas sample $=200 \mu \mathrm{L}$.

Using the calibration curve, the individual volume of $\mathrm{Cn} \mathrm{HC}\left(\mathrm{V}_{\mathrm{Cn}-\mathrm{HC}}\right)$ in the injected gas products can be obtained. Notice that $\mathrm{HCs}$ with a $\mathrm{Cn}$ value higher than seven are trace components and are thus assumed to be negligible. The volume percentage of each hydrocarbon of C1-C6 in gaseous HCs with a sum of $100 \%$ is shown in Figure 5. The C4 HC expressed, equivalent to butane, is the major compound of the gaseous hydrocarbons. Hydrocarbons other than $\mathrm{C} 4 \mathrm{HC}$ are also obviously present.

Knowing that the volume of the gas products injected into GC-FID $\left(\mathrm{V}_{\mathrm{I}}\right)$ is $200 \mu \mathrm{L}$ and that the total gas products with the carrier gas $\left(\mathrm{V}_{\mathrm{T}}\right)$ is $4183 \mathrm{~mL}$, the total volume of all $\mathrm{Cn}$ HCs with $\mathrm{n}=1$ to 6 $\left(\mathrm{V}_{\mathrm{THC}}\right)$ in the gas products could be calculated by assuming that all of the gas products are ideal gas. The applicable equation can be seen below.

$$
\mathrm{V}_{\mathrm{THC}}=\left(\left(\text { Sum of } \mathrm{V}_{\mathrm{Cn}-\mathrm{HC}}\right) / \mathrm{V}_{\mathrm{I}}\right) \times \mathrm{V}_{\mathrm{T}}
$$

Using this equation, the total volume of hydrocarbons when concerning only C1-C6 HCs is $1.74 \mathrm{~mL}$. 


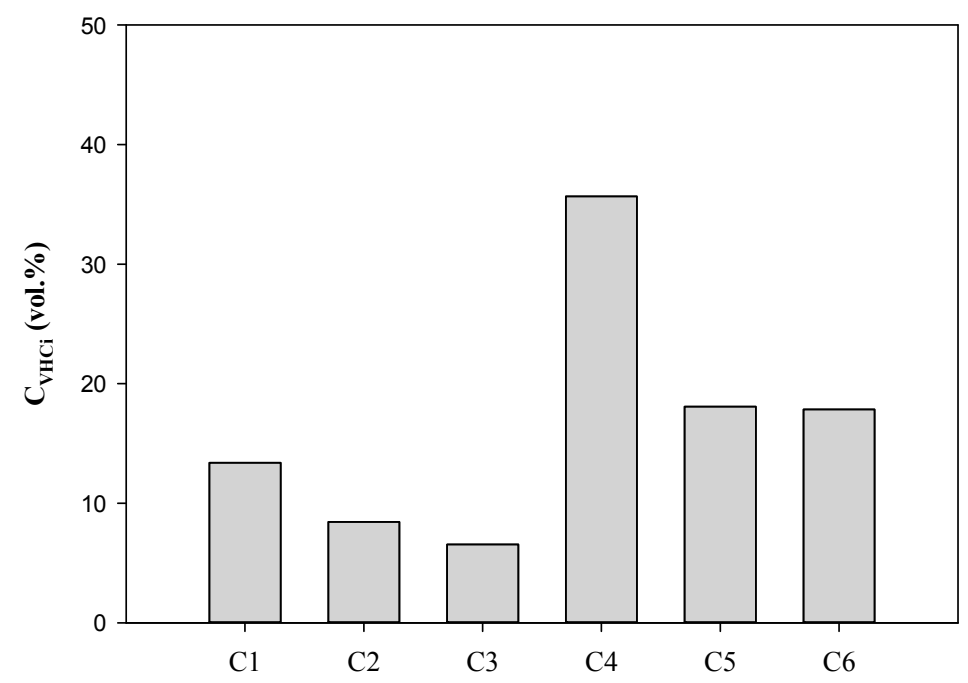

Figure 5. Volume concentration of compounds of hydrocarbons (HCs) in gaseous HCs from the torrefaction of WBC at $563 \mathrm{~K}$ and $40 \mathrm{~min}$. C1-C6: HC with 1 to 6 carbons. Hydrocarbons other than C1-C6 HC are negligible.

\subsection{2. $\mathrm{CO}, \mathrm{NO}_{\mathrm{x}}, \mathrm{SO}_{2}$, and $\mathrm{CO}_{2}$}

By using a gas detector, $\mathrm{CO}, \mathrm{NO}_{\mathrm{x}}$, and $\mathrm{SO}_{2}$ from the gas products are continually detected per minute from the $40 \mathrm{~min}$ torrefaction process. The diagrams which illustrate the relationship between the concentration of emissions and the residence time of torrefaction are established. Taking an example in Figure 6 for the $\mathrm{CO}$ emission from the torrefaction of $\mathrm{WBC}_{\mathrm{T}}$, average gas concentrations with the error bars standing for the standard deviation from repetitive analyses are shown.

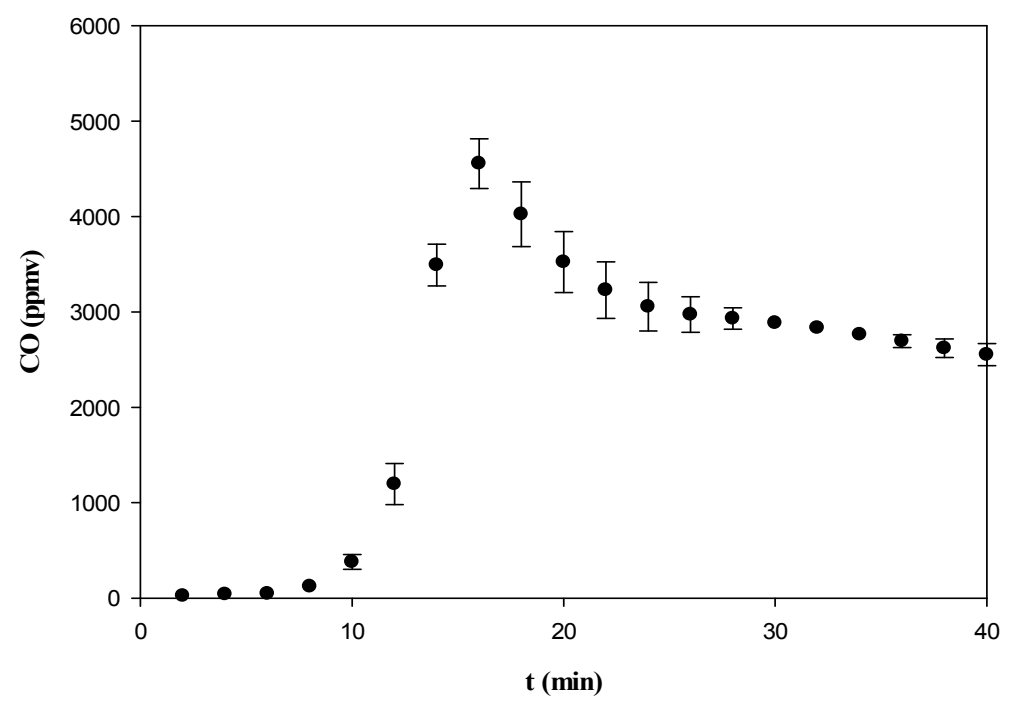

Figure 6. Emissions of CO from the torrefaction of WBC at $563 \mathrm{~K}$ and $40 \mathrm{~min}$.

According to continual emissions analysis, the trend of emission can be observed. In Figures 6-8, $\mathrm{CO}, \mathrm{NO}_{\mathrm{x}}$, and $\mathrm{SO}_{2}$ all start to appear at around $8 \mathrm{~min}$, so it is an indisputable fact that pyrolysis occurs after $8 \mathrm{~min}$ of torrefaction. When the time reaches $16 \mathrm{~min}$, the maximal peak of $\mathrm{CO}$ appears and the value arrives at $4500 \mathrm{ppmv}$ in total gas, including the carrier gas nitrogen (Figure 6). As for $\mathrm{NO}_{\mathrm{x}}$, there is no explicit peak and the concentration of $\mathrm{NO}_{\mathrm{x}}$ is maintained at around $60 \mathrm{ppmv}$ until the end of process (Figure 7). Besides, $\mathrm{SO}_{2}$ had a maximum concentration of $58 \mathrm{ppmv}$ at around $12 \mathrm{~min}$ (Figure 8). The reason for the emission of $\mathrm{SO}_{2}$ is that disposable chopsticks are pretreated by an oxidizer such as 
bleach, which includes the component of sulfur, and the amount of bleach used for each chopstick has an influence on the results.

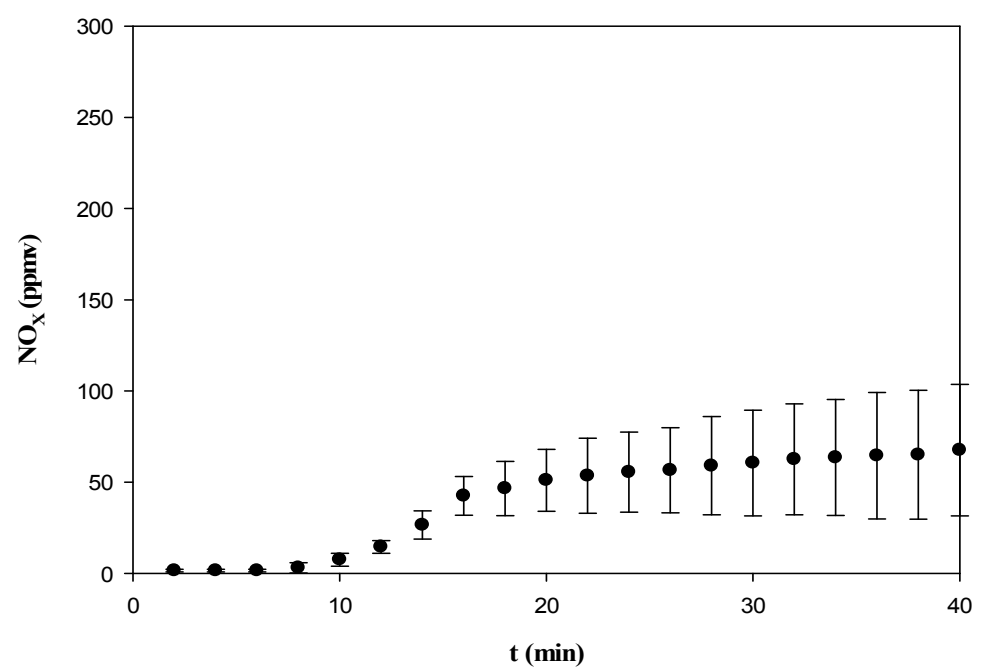

Figure 7. Emissions of $\mathrm{NO}_{\mathrm{x}}$ from the torrefaction of $\mathrm{WBC}$ at $563 \mathrm{~K}$ and $40 \mathrm{~min}$.

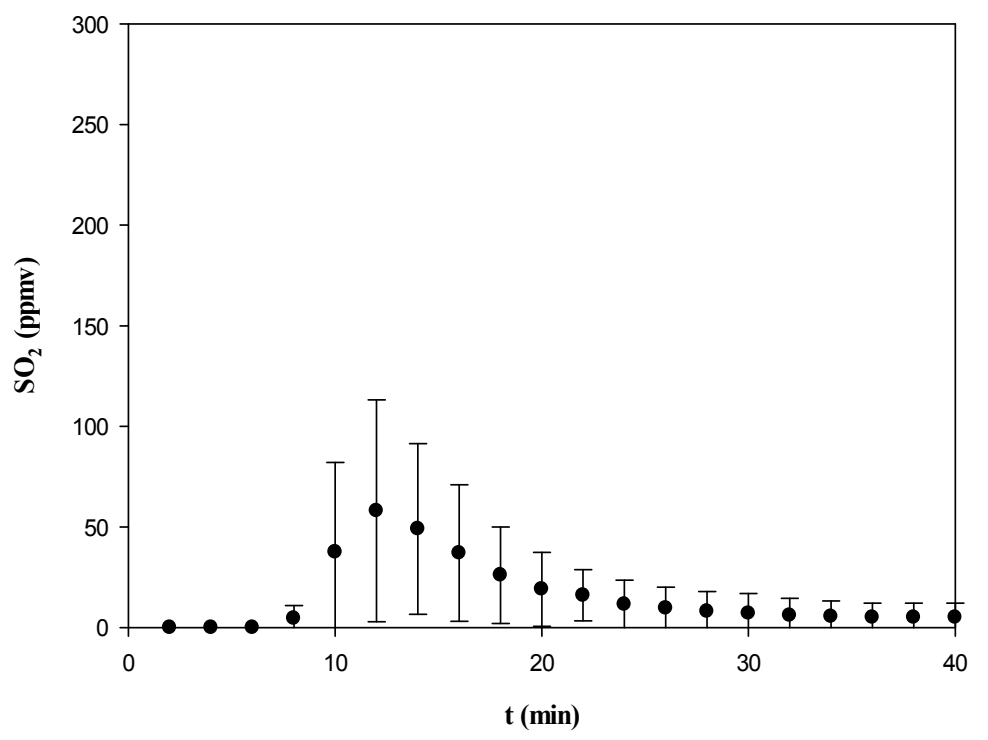

Figure 8. Emissions of $\mathrm{SO}_{2}$ from the torrefaction of $\mathrm{WBC}$ at $563 \mathrm{~K}$ and $40 \mathrm{~min}$.

By sampling gas products every $10 \mathrm{~min}$ with a gas bag, the trend of $\mathrm{CO}_{2}$ emission through torrefaction could be constructed. The concentrations of $\mathrm{CO}_{2}$ in the gas bags represent the instant concentrations of 5, 15, 25, and 35 min through the 40 min torrefaction process. In Figure 9, the maximum value appears at around $15 \mathrm{~min}$ with a $\mathrm{CO}_{2}$ measurement of $1.94 \mathrm{vol} \%$.

In summary, the most intense pyrolysis of torrection takes place between the retention time of $10 \mathrm{~min}$ to $20 \mathrm{~min}$, which has a maximum of instant concentration of each gas except $\mathrm{NO}_{\mathrm{x}}$. During $40 \mathrm{~min}$ of torrefaction, except $\mathrm{SO}_{x}$, the instant concentrations of gases are still maintained at a considerable amount at the last minute of torrefaction. As a result, the pyrolysis could continue after $40 \mathrm{~min}$ of torrefaction and it still takes time to reach the levelling off of the concentration values of emitted gases such as CO. 


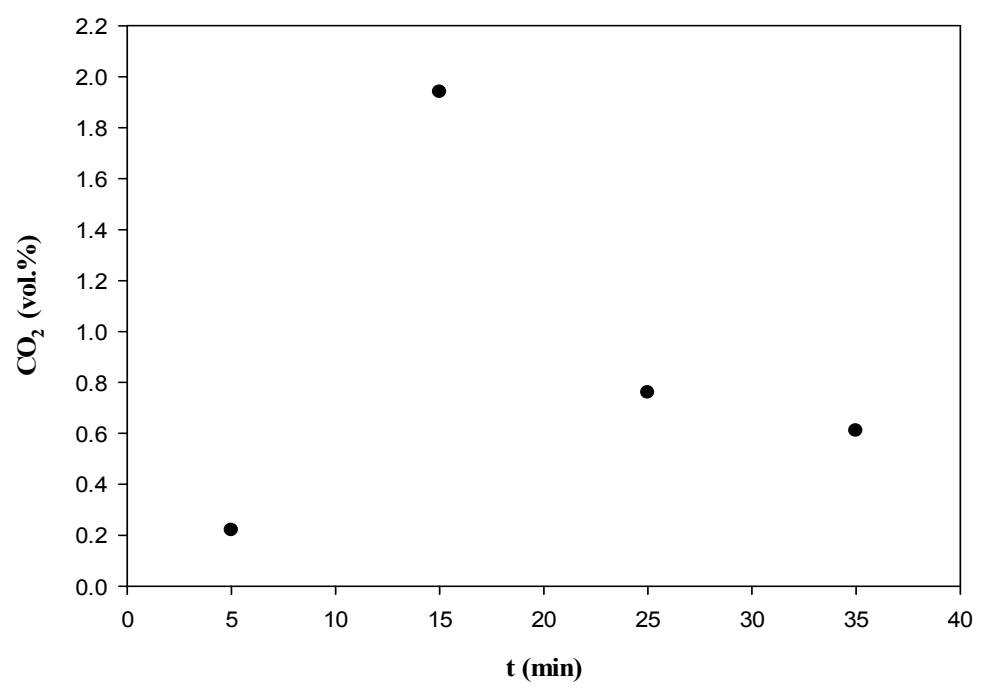

Figure 9. Emissions of $\mathrm{CO}_{2}$ from the torrefaction of $\mathrm{WBC}$ at $563 \mathrm{~K}$ and $40 \mathrm{~min}$.

\subsubsection{Gas Balance}

After collecting all of the gas products from $40 \mathrm{~min}$ of the process of torrefaction, the average concentration of each kind of gas could be measured by a gas analyzer. $\mathrm{SO}_{2}$ and $\mathrm{NO}_{\mathrm{x}}$ only occupy a small part of the gas products. The average concentrations of $\mathrm{SO}_{2}$ and $\mathrm{NO}_{\mathrm{x}}$ are 37.7 and $75.3 \mathrm{ppmv}$, respectively. The $\mathrm{SO}_{2}$ and $\mathrm{NO}_{x}$ of a low amount are neglected to create a volume data of each gas, as shown in Table 4 . By using the total volume of the output gas including $\mathrm{N}_{2}\left(\mathrm{~V}_{\mathrm{G}+\mathrm{N}}\right)$ and the volume concentration $\left(\mathrm{C}_{\mathrm{VGNi}}\right)$ of each component in $\mathrm{V}_{\mathrm{G}+\mathrm{N}}$, the individual gas volume $\left(\mathrm{V}_{\mathrm{Gi}}\right)$ could be counted. The equation is listed below:

$$
\mathrm{V}_{\mathrm{Gi}}=\mathrm{C}_{\mathrm{VGNi}} \times \mathrm{V}_{\mathrm{G}+\mathrm{N}}
$$

Summing $\mathrm{V}_{\mathrm{Gi}}$ for all $\mathrm{i}$ components then gives a total volume of gases excluding $\mathrm{N}_{2}$.

Table 4. Volume of different compounds in the gas products from the torrefaction of WBC at $563 \mathrm{~K}$ and $40 \mathrm{~min}$.

\begin{tabular}{cc}
\hline Compound & Volume (mL) \\
\hline $\mathrm{O}_{2}{ }^{\mathrm{a}}$ & 79.5 \\
$\mathrm{CO}^{\mathrm{b}}$ & 16.2 \\
$\mathrm{C} 1-\mathrm{C} 6 \mathrm{HCs}$ & 1.74 \\
$\mathrm{C} 1 \mathrm{HC}$ & 0.19 \\
$\mathrm{C} 2-\mathrm{C}^{\mathrm{HC}} \mathrm{HC}$ & 1.55 \\
$\mathrm{CO}_{2}{ }^{\mathrm{c}}$ & 41.4 \\
$\mathrm{H}_{2} \mathrm{O}^{\mathrm{d}}$ & 51.2 \\
Total $^{-1}$ & 190 \\
Total gases measured from flowmeter & 183
\end{tabular}

a Volume concentration of $\mathrm{O}_{2}$ in total output gas including $\mathrm{N}_{2}\left(\mathrm{~V}_{\mathrm{G}+\mathrm{N}}=4183 \mathrm{~mL}\right)=1.9 \%$. ${ }^{\mathrm{b}}$ Volume concentration of $\mathrm{CO}$ in $\mathrm{V}_{\mathrm{G}+\mathrm{N}}=3863.7$ ppmv. ${ }^{\mathrm{c}}$ Volume concentration of $\mathrm{CO}_{2}$ in $\mathrm{V}_{\mathrm{G}+\mathrm{N}}=0.99 \%$. ${ }^{\mathrm{d}}$ Relative humidity in gas $=40.7 \%$ at $24.3^{\circ} \mathrm{C}$, assuming $1 \mathrm{~atm}$. Humidity is $9.00 \mathrm{~g} \mathrm{~m}^{-3}$. From ideal gas equation, volume of $\mathrm{H}_{2} \mathrm{O}$ can be obtained. e Estimated as difference of $\mathrm{V}_{\mathrm{G}+\mathrm{N}}$ and $\mathrm{V}_{\mathrm{N}}$ (volume of inlet $\mathrm{N}_{2}$ ) with $\mathrm{V}_{\mathrm{N}}=4000 \mathrm{~mL}$.

According to Table 4, oxygen, carbon dioxide, and moisture are the major gases emitted. It is noted that, although the reactor was pre-purged by nitrogen to remove the air, during the charging of the sample into the reactor, some air with moisture was able to flow in. Moreover, the leakages of the torrefaction equipment could cause errors in the measurement of the collected gas products. Accordingly, these causes would affect the measurements of the components of atmosphere like the $\mathrm{O}_{2}, \mathrm{CO}_{2}$, and $\mathrm{H}_{2} \mathrm{O}$ in the gas products. Detailed procedures of pre-purging of air by nitrogen before 
torrefaction are as follows. The torrefaction of WBC was conducted by employing a tubular furnace with a volume of $3393 \mathrm{~mL}$ ( $30 \mathrm{~cm}$ in length and $12 \mathrm{~cm}$ in inside diameter). Every time before conducting torrefaction, nitrogen with a flow rate of $300 \mathrm{~mL} \mathrm{~min}^{-1}$ (three times the flow rate used for torrefaction) was introduced continuously into the furnace for $30 \mathrm{~min}$ ( $9000 \mathrm{~mL}$ of nitrogen), until a stable pre-set torrefaction temperature was reached. As a result, by assuming an ideal reactor, the hydraulic retention time $(\tau)$ is $11.3 \mathrm{~min}(=3393 / 300)$, while the purging time of nitrogen $\left(t_{N}\right)$ is $2.6(=30 / 11.3)$ times the $\tau$ value. The fractional concentration of residual oxygen $\left(C / C_{0}\right)$ is $0.074\left(=\exp \left(-t_{N} / \tau\right)=\exp (-2.6)\right)$. For $C / C_{0}=0.5, t_{N}=3 \tau=33.9 \mathrm{~min}$, which is comparable to a torrefaction time $t_{r}$ of 20,40 , and 60 min tested, and close to the purging time $t_{\mathrm{N}}$ of $30 \mathrm{~min}$. Thus, oxygen would be mostly removed by a great amount of nitrogen with $2.6 \tau$ through the outlet in the end tail in the air purged procedure using nitrogen.

It is worth comparing the sum of volumes of gases excluding $\mathrm{N}_{2}$ in Table $4(190 \mathrm{~mL})$, which were directly measured by a gas analyzer with the volume of non- $\mathrm{N}_{2}$ gas products in Table $1(183 \mathrm{~mL})$, which is estimated from the flowrates via a flowmeter during the experiment. The comparison shows that the two values determined by the different methods are close. Therefore, the volume of the gas product is about $183-190 \mathrm{~mL}$.

According to the gas analyses of Table 4, the volume fractions of the component gases can be presented, as in Figure 10. The results indicate that non-hydrocarbons (NHC) are the main compounds in the gas products, excluding the carrier nitrogen. $\mathrm{CH}_{4}(\mathrm{C} 1 \mathrm{HC})$ and other $\mathrm{HCs}$ of $\mathrm{C} 2-\mathrm{C} 6 \mathrm{HCs}$ only occupy $0.11 \mathrm{vol} \%$ and $0.91 \mathrm{vol} \%$, respectively, of the total emissions, excluding the carrier nitrogen. The essential HCs contain C1-C6 HCs.

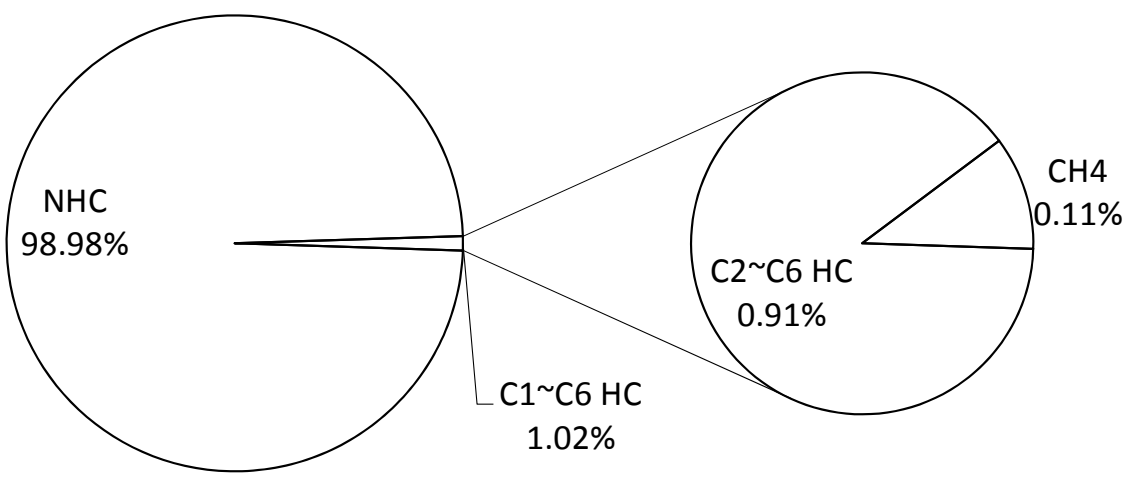

Figure 10. Volume percentage of non-hydrocarbons (NHC), $\mathrm{C} 1-\mathrm{C} 6 \mathrm{HC}, \mathrm{C} 2-\mathrm{C} 6 \mathrm{HC}$, and $\mathrm{CH}_{4}$ in the gaseous products from the torrefaction of $\mathrm{WBC}$ at $563 \mathrm{~K}$ and $40 \mathrm{~min}$, excluding the carrier nitrogen. Hydrocarbons other than $\mathrm{C} 1-\mathrm{C} 6 \mathrm{HC}$ are negligible.

The possible application of gas products may be assessed by considering their fuel components in a gas mixture which consists of carbon monoxide, hydrogen, methane, and C2-C6 HCs. As seen in Table 3 and Figure 10, the gas products entail $0.11 \mathrm{vol} \%$ of $\mathrm{CH}_{4}, 0.91 \mathrm{vol} \%$ of $\mathrm{C} 2-\mathrm{C} 6 \mathrm{HCs}$, and $8.85 \mathrm{vol} \%$ of $\mathrm{CO}$ in $183 \mathrm{~mL}$ of gas product from torrefaction, excluding the carrier nitrogen. After proper purification and concentrating, these enriched combustible gases can be used as gas fuel.

\subsubsection{Comparison of Gas Emissions with Air Pollution Standards}

Table 5 compares the maximum gas emissions from torrefaction with emission standards of stationary sources (ESSS) of Taiwan Environmental Protection Administration (TEPA) [19]. Although the emissions of $\mathrm{SO}_{2}$ and $\mathrm{NO}_{2}$ meet the regulations, that of $\mathrm{CO}$ exceeds the ESSS of TEPA. Thus, proper air pollution control measures are needed. 
Table 5. Comparison of gas emissions with air pollution standards.

\begin{tabular}{ccc}
\hline Item & $\begin{array}{c}\text { Emission Standards } \mathbf{a}^{\mathbf{a}} \\
(\mathbf{p} \text { pmv) }\end{array}$ & $\begin{array}{c}\text { Maximum Concentration through Torrefaction } \\
\text { (ppmv) }\end{array}$ \\
\hline $\mathrm{SO}_{2}$ & 650 & 58.0 \\
$\mathrm{NO}_{2}$ & 250 & $67.5^{\mathrm{b}}$ \\
$\mathrm{CO}$ & 2000 & 4555.5 \\
\hline
\end{tabular}

a Emission standards of stationary sources in Taiwan [19]. Velocity of wind: $3.5 \mathrm{~m} \mathrm{~s}^{-1} ; \mathrm{SO}_{2}$ and $\mathrm{NO}_{2}$ : Standards of processes excluding combustion. ${ }^{\mathrm{b}}$ Actually concentration of $\mathrm{NO}_{\mathrm{x}}$.

\section{Conclusions}

1. The $\mathrm{pH}$ value of the liquid products is about 0.96 , which demonstrates that some preprocesses used for removing acidic components are necessary to more usefully reuse these products.

2. With the exception of the water content, the major components of the liquid products are organic matters with a low carbon number below $\mathrm{C} 6$.

3. There are some useful compounds appearing in the liquid. The main components can be reformed to produced long-chain alkanes, forming diesel fuel (C10-C40) and aviation fuel (C10-C20).

4. The liquid contains some useful medicinal components like C23 prednisolone acetate and C22 colchicine.

5. Proper air pollution control measures are needed for avoiding air pollution resulting from the torrefaction of WBC.

6. Gas products from the large scale torrefaction of WBC represent chance to develop the utilization of biogas (alkanes).

Acknowledgments: The authors are grateful for the financial support of this research provided by the Ministry of Science and Technology (formerly the National Science Council) of Taiwan.

Author Contributions: Yen-Hau Chen, Chia-Chi Chang and Ching-Yuan Chang conceived and designed the experiments; Yen-Hau Chen, Wei-Ren Chang, Tzu-Yi Yang, Tsung-Chi Hsu and Michael Huang performed the experiments; Yen-Hau Chen, Michael Huang and Min-Hao Yuan analyzed the data; Dar-Ren Ji, Chungfang Ho, Chyow-San Chiou, Je-Lueng Shie, Yi-Hung Chen, Chao-Hsiung Wu and Far-Ching Lin contributed reagents/materials/analysis tools; Yen-Hau Chen, Chia-Chi Chang, Min-Hao Yuan and Ching-Yuan Chang wrote the paper.

Conflicts of Interest: The authors declare no conflict of interest.

\section{Nomenclature}

\begin{tabular}{|c|c|}
\hline bp & Boiling point $(\mathrm{K})$ \\
\hline $\mathrm{Cn}$ & Number of carbons (-) \\
\hline $\mathrm{C}_{\mathrm{TOC}}$ & Concentration of TOC $\left(\mathrm{mg} \mathrm{L}^{-1}\right)$ \\
\hline $\mathrm{C}_{\mathrm{VGNi}}$ & Volume concentration of component $\mathrm{i}$ in total gas including $\mathrm{N}_{2}(\mathrm{vol} \%)$ \\
\hline $\mathrm{C}_{\mathrm{VHCi}}$ & Volume concentration of individual hydrocarbon i in total $\mathrm{HCs}$ (vol \%) \\
\hline $\mathrm{E}_{\mathrm{D}}$ & Energy densification factor (-) \\
\hline $\mathrm{H}_{\mathrm{HD}}$ & High heating value in dry basis $\left(\mathrm{kcal} \mathrm{kg}^{-1}\right)$ \\
\hline M & Mass content (wt \%) \\
\hline $\mathrm{M}_{\mathrm{TOC}}$ & Mass percent of TOC (wt \%) \\
\hline $\mathrm{m}_{\mathrm{L}}$ & Mass of liquid product $(\mathrm{g})$ \\
\hline$Q_{G e}$ & Average flow rate of exist gas $\left(\mathrm{mL} \mathrm{min}^{-1}\right)$ \\
\hline $\mathrm{Q}_{\mathrm{Ni}}$ & Average flow rate of inlet $\mathrm{N}_{2}\left(\mathrm{~mL} \min ^{-1}\right), 100 \mathrm{~mL} \mathrm{\operatorname {min } ^ { - 1 }}$ \\
\hline $\mathrm{T}_{\mathrm{r}}$ or $\mathrm{T}_{\text {tor }}$ & Torrefaction temperature $(\mathrm{K})$ \\
\hline$t_{r}$ or $t_{\text {reaction }}$ & Torrefaction time (min) \\
\hline $\mathrm{V}_{\mathrm{Cn}-\mathrm{HC}}$ & Volume of $\mathrm{Cn} \mathrm{HC}(\mathrm{mL})$ \\
\hline $\mathrm{V}_{\mathrm{G}+\mathrm{N}}$ or $\mathrm{V}_{\mathrm{T}}$ & Volume of total output gas including carrier gas $\mathrm{N}_{2}(\mathrm{~mL}), 4183 \mathrm{~mL}$ \\
\hline $\mathrm{V}_{\mathrm{Gi}}$ & Gas volume of component i (mL) \\
\hline $\mathrm{V}_{\mathrm{I}}$ & Volume of gas products injected into GC-FID $(\mu \mathrm{L}), 200 \mu \mathrm{L}$ \\
\hline $\mathrm{V}_{\mathrm{L}}$ & Volume of liquid product (mL) \\
\hline
\end{tabular}




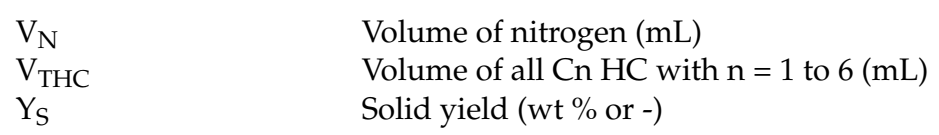

\section{Abbreviation}

$\begin{array}{ll}\text { AAQS } & \text { Ambient air quality standards } \\ \text { DBCs } & \text { Disposable bamboo chopsticks } \\ \text { DCs } & \text { Disposable chopsticks } \\ \text { ESSS } & \text { Emission standards of stationary sources } \\ \text { FID } & \text { Flame ionization detector } \\ \text { GC } & \text { Gas chromatography } \\ \text { GC-MS } & \text { GC with mass spectrum } \\ \text { HCs } & \text { Hydrocarbons } \\ \text { TEPA } & \text { Taiwan Environmental Protection Administration } \\ \text { TOC } & \text { Total organic carbon } \\ \text { WBCs } & \text { Waste bamboo chopsticks } \\ \text { WBC } & \text { Torrefied waste bamboo chopsticks }\end{array}$

\section{References}

1. Arcate, J. New process for torrefied wood manufacturing. Bioenergy Update 2000, 4, 1-4.

2. Arias, B.; Pevida, C.; Fermoso, J.; Plaza, M.G.; Rubiera, F. Influence of torrefaction on the grindability and reactivity of wood biomass. Fuel Process. Technol. 2008, 89, 169-175. [CrossRef]

3. Chen, W.H.; Peng, J.H.; Bi, X.T.T. A state-of-the-art review of biomass torrefaction, densification and applications. Renew. Sustain. Energy Reviews 2015, 44, 847-866. [CrossRef]

4. Eseyin, A.E.; Steele, P.H.; Pittman, C.U. Current trends in the production and applications of torrefied wood/biomass-A review. BioResources 2015, 10, 8812-8858. [CrossRef]

5. Bergman, P.C.A.; Boersma, A.R.; Zwart, R.W.R.; Kiel, J.H.A. Torrefaction for Biomass Co-Firing in Existing Coal-fired Power Stations, in "Biocoal"; Report ECN-C-05-013; Energy Research Center of the Netherlands: Petten, The Netherlands, 2005.

6. Şensöz, S. Slow pyrolysis of wood barks from Pinus brutia Ten and product compositions. Bioresource Technol. 2003, 89, 307-311. [CrossRef]

7. Zhang, S.; Yan, Y.; Li, T.; Ren, Z. Upgrading of liquid fuel from the pyrolysis of biomass. Bioresource Technol. 2005, 96, 545-550. [CrossRef] [PubMed]

8. Saizjimenez, C.; Deleeuw, J.W. Lignin pyrolysis products: Their structures and their significance as biomarkers. Organic Geochem. 1986, 10, 869-876. [CrossRef]

9. Chen, W.H.; Hsu, H.C.; Lu, K.M.; Lee, W.J.; Lin, T.C. Thermal pretreatment of wood (Lauan) block by torrefaction and its influence on the properties of the biomass. Energy 2011, 36, 3012-3021. [CrossRef]

10. Chen, W.H.; Liu, S.H.; Juang, T.T.; Tsai, C.M.; Zhuang, Y.Q. Characterization of solid and liquid products from bamboo torrefaction. Appl. Energ. 2015, 160, 829-835. [CrossRef]

11. Prins, M.J.; Ptasinski, K.J.; Janssen, F.J.J.G. Torrefaction of wood-Part 2. Analysis of products. J. Anal. Appl. Pyrol. 2006, 77, 35-40. [CrossRef]

12. Chen, Y.H.; Chang, C.C.; Chang, C.Y.; Yuan, M.H.; Ji, D.R.; Shie, J.L.; Chen, Y.H.; Chang, W.R.; Yang, T.Y.; Lee, C.H.; et al. Production of Solid Bio-fuel from Waste Bamboo Chopsticks by Torrefaction. J. Anal. Appl. Pyrol. 2017. (Under review).

13. Biswas, A.; Mahanta, P. Design and experimental analysis of condenser for the production of bamboo vinegar. Int. J. Appl. Res. Mech. Eng. 2012, 2, 79-86.

14. Hung, Z.S.; Chang, C.C.; Chang, C.F.H.; Lin, Y.S.; Ji, D.R.; Chang, C.Y.; Tseng, J.Y.; Chiang, S.W.; Shie, J.S.; Chen, Y.H.; et al. Autoclaving treatment of wasted disposable bamboo chopsticks. J. Taiwan Inst. Chem. Eng. 2013, 44, 1010-1015. [CrossRef]

15. Lê Thànha, K.; Commandréa, J.M.; Valettea, J.; Vollea, G.; Meyerb, M. Detailed identification and quantification of the condensable species released during torrefaction of lignocellulosic biomasses. Fuel Process. Technol. 2015, 139, 226-235. [CrossRef] 
16. Chang, C.C.; Chen, C.P.; Yang, C.S.; Chen, Y.H.; Huang, M.; Chang, C.Y.; Shie, J.L.; Yuan, M.H.; Chen, Y.H.; Ho, C.; et al. Conversion of waste bamboo chopsticks to bio-oil via catalytic hydrothermal liquefaction using $\mathrm{K}_{2} \mathrm{CO}_{3}$. Sustain. Environ. Res. 2016, 26, 262-267. [CrossRef]

17. Wang, Z.; Lin, W.; Song, W.; Yao, J. Preliminary investigation on concentrating of acetol from wood vinegar. Energy Convers. Manag. 2010, 51, 346-349. [CrossRef]

18. Sanders, J.; Scott, E.; Weusthuis, R.A.; Mooibroek, H. Bio-refinery as the bio-inspired process to bulk chemicals. Macromol. Biosci. 2007, 7, 105-117. [CrossRef] [PubMed]

19. TEPA (Taiwan Environmental Protection Administration). Emission Standards of Stationary Sources (ESSS). Available online: http:/ /ivy5.epa.gov.tw/docfile/040070.pdf (accessed on 24 June 2016).

2017 by the authors. Licensee MDPI, Basel, Switzerland. This article is an open access article distributed under the terms and conditions of the Creative Commons Attribution (CC BY) license (http://creativecommons.org/licenses/by/4.0/). 